THURSDAY, DECEMBER 25, r913.

\section{THE PEOPLING OF MELANESIA.}

Wissenschaftliche Ergebnisse einer amtlichen Forschungsreise nach dem Bismarck-Archipel im Jahre 1908. III. Untersuchungen über eine melanesische Wanderstrasse. Von Dr. Georg Friederici. [Mitteilungen aus dem Deutschen Schutzgebieten. Ergänzungsheft Nr. 7.] Pp. iii + 182. (Berlin: E. S. Mittler und Sohn, I913.) Price 3.60 marks.

$\mathrm{N}$ this volume Dr. Friederici has used the results of his personal inquiries into the linguistics and ethnology of the Bismarck Archipelago in an endeavour to trace the path of the Melanesian people from Indonesia to their present settlements east and south of New Guinea.

In the second volume of the "Results" of the Hanseatic South Sea Expedition of 1908 Dr. Friederici gave a compendious account of the ethnography and languages of the archipelago, with special studies of certain implements and navigation. From these he concluded that there was evidence of a considerable connection between the people of the Bismarck Archipelago and those of the region roughly indicated by a line drawn from the Southern Philippines across north-east Celebes, to the Moluccas in the neighbourhood of Ceram and Buru. The present volume deals with the evidence in more detail. A comparison of the languages of the Barriai and related peoples of North New Pommern shows many agreements in grammar and vocabulary with the group of languages known as the Bahasa Tanah of the Alfurus (or inlanders) of Ceram and the adjacent Moluccan islands, and Dr. Friederici concludes that the Melanesians originally came from that region, though they were considerably modified by another stream of immigrants from the region included between the Southern Philippines, North Borneo, and the Minahasa peninsula of Celebes. On reaching the Bismarck Archipelago a portion of the Moluccan swarm passed through Vitiaz Strait and settled along the coast of south and south-eastern New Guinea. Another portion, after colonising the shores of New Pommern and New Mecklenburg, passed through Dampier Strait to the northern islands of the Louisiades, the Southern Solomons, and the New Hebrides. The immigrants from the sub-Philippine region took a more northerly route by the Admiralty group to New Hanover, East New Mecklenburg, and the Solomon Islands.

Although his argument is based mainly on the languages, Dr. Friederici recognises the difficulties in definitely fixing the position of the Melanesians, which arise from their great variation in physical appearance and culture. But he maintains that a NO. 2304, VOL. 92$]$ close agreement in the fundamental structure of the languages and the presence in them of important and numerous common words is evidence of the presence of the carriers of the languages in the places where they are now found. He points out also a number of ethnological facts which support the conclusions based on linguistics.

Dr. Friederici's book will be found of much value to the student of oceanic ethnology. It increases very considerably our knowledge of the languages of the Bismarck Archipelago. It affords a satisfactory indication of at least one path by which the speakers of Melanesian languages entered the Pacific, though it leaves still unsolved the problems of the northern and eastern Pacific, and the details of the dispersal of the Melanesian swarm after its passage through the Vitiaz and Dampier channels.

The work would have been improved by an index, and in the absence of a purely linguistic map of the archipelago there is some difficulty in locating the languages. The names do not always agree with those appearing on maps in former volumes of the "Results." Sidney H. Ray.

REGIONAL AND GENERAL GEOGRAPHY.

(I) Tirol, Vorarlberg und Liechtenstein. By Prof. K. W. von Dalla Torre. Pp. xxiv +486 . (Berlin: W. Junk, I9I3.) Price 6 marks.

(2) Mittelmeerbilder. Gesammelte Abhandlungen zur Kunde der Mittelmeerländer. By Dr. Theobald Fischer. Zweite Auflage, besorgt von Dr. A. Rühl. Pp. vi $+47^{2}$. (Leipzig and Berlin: B. G. Teubner, I9I3.) Price 7 marks. (3) La Région du Haut Tell en Tunisie. (Le Kef, Téboursouk, Mactar, Thala) Essai de Monographie Géographique. By Dr. Ch. Monchicourt. Pp. xiv $+487+$ plates. (Paris : Librairie Armand Colin, i9r3.) Price I2 francs.

(4) Animal Geography: The Faunas of the Natural Regions of the Globe. By Dr. M. I. Newbigin. Pp. 238. (Oxford: Clarendon Press, 1913.) Price $4 s .6 d$.

(5) A Commercial Geography of the World. By O. J. R. Howarth. Pp. 236. (Oxford: Clarendon Press, 19r3.) Price 2s. $6 d$.

(I) ROF. VON DALLA TORRE'S contribution to Junk's "Natur-Führer" is produced in the well-known style of "Baedeker's Guides," and is a scientific companion for the pedestrian or the cyclist. The commonplace details as to hotels and meals, railway-tickets, and gratuities to custodians, are omitted altogether; in their place we find a truly marvellous amount of information on natural phenomena, from scenic details to botanical species, arranged topographically, just as we come across them on the 